\title{
Research of Development for Higher Education Innovation
}

\author{
Shang Miao \\ Mechanical and electrical technology department \\ Xijing University, \\ Shaanxi Xi'an ,China \\ e-mail: 445700839@qq.com
}

\author{
Li Jiabin \\ Mechanical and electrical technology department \\ Xijing University, \\ Shaanxi Xi'an ,China \\ e-mail: 1067803816@qq.com
}

\author{
Ju Chunfei \\ Mechanical and electrical technology department \\ Xijing University, \\ Shaanxi Xi'an, China \\ e-mail: 344062195@qq.com \\ Fang Yingbao
Mechanical and electrical technology department
Xijing University,
Shaanxi Xi'an ,China
e-mail: 2941100857@qq.com

\begin{abstract}
With the rapid development of our country's economy, higher education pay more attention to the cultivation of applied talents. Reference to enterprise training mode of university that plays an important role in the development of higher education. In this paper, the boundary of the higher education development are analyzed by corporate universities, and the development mainly includes the higher education personnel training mode, learning form of higher education and structure of higher education; The innovation of higher education is to promote through corporate universities, the innovation of higher education mainly include higher education's diversification, the informatization of higher education, and the system innovation of higher education. Corporate universities promote the development of higher education towards diversification and informationization. Development of higher education innovation is inspired by the enterprise university, and it is of great significance for the innovation and development of higher education.
\end{abstract}

Keywords-higher education; corporate university; innovation ability; talent training; diversified patterns

\section{INTRODUCTION}

Higher education are playing an increasingly important role in the knowledge economy society, social production practices influence on modern higher education is more and more significant, promoting the development of modern higher education. Rooted in the production practice of corporate universities with congenital advantage, combining the production practice of the knowledge production relations to adapt and promoting the development of the productivity of knowledge, combining with the production practice of knowledge production service mode accords with the objective law of knowledge development, it can meet the need of social development, corporate universities in the era of knowledge economy booming and shows strong vitality. Enterprise way of business [1], the success of the university of the innovation and development of modern higher education necessarily has the important enlightenment to university development is of important value for the 21 st century.

\section{DEVELOPMENT OF THE HIGHER EDUCATION BOUNDARY}

\section{A. Corporate university is an important part of higher education}

With the specialization of higher education is becoming more and more developed, higher education had great changes in the size, type, level, form. The connotation of higher education is constantly enrich. Their awareness of higher education also in constant development [2]. Higher education consists of academic education, high vocational and professional education. So higher education more widely than academic education.

When higher education entered the popular phase, the proportion of in-service education is more and more big. As members of the enterprise employees have received higher education continues to increase, so the university is not only to the enterprises engaging in on-the-job continuing education after secondary school education, and is likely to be after university education. This causes the corporate university from content to form must be continuously to high-end ascending, the nature of the corporate universities which belong to category of higher vocational education.

Promoted the rapid update of knowledge, knowledge economy human capital development is no longer once and for all. Adult education, continuing education and lifelong education more and more important. On-the-job continuing education can not only make business backbone, industry experts and executives, can help enterprise organization development and national economic development to provide intellectual support. Therefore, onthe-job education demand is particularly urgent. And its development is also more rapidly [3]. As a new force of modern higher education, university of enterprises will gradually become the main about on-the-job continuing education. Higher vocational education become an important organization part of higher vocational education, adult education, continuing education and lifelong education. 


\section{B. Corporate universities expand the boundary of the higher education}

The traditional higher education and other industries, it is based on the specialization of social division of labor and specialized in the industry of higher education. Specialization to improve the efficiency of higher education, but also make the traditional higher education is relatively independent of other social field production practice.

Although higher education institutions is close connection with the practice of social production, at the same time it adapted to the social development to a certain extent, meet the needs of the production practice. But they has certain limitation and they still can't completely and the integration of production practice [4]. With the development of knowledge economy, the production practice has become an important source of knowledge innovation. Rooted in the maternal arises at the historic moment, the production practice of enterprise university knowledge production service for the parent companies and the integration of production practice, meet the needs of the enterprise production practice.

\section{Corporate universities expand the higher education personnel training mode}

Corporate university personnel training is complete and the integration of enterprise's production practice. It is hard to achieve higher education institutions, it is also an indispensable part of the training applied talents. Advanced applied talents, including executives and business elite, management talent, industry experts such as science and technology, science and technology elite talent, business backbone, such as expert skilled talents [5]. They are corporate university learners, innovators, is also the production of business practitioners. They are the core value of core talents for the enterprise to create. And the integration of the production practice of talent training mode is the elite culture. This model helps to improve the high quality and efficiency of the applied talents training. The cultivation of applied talents can't be from began to the production practice.

Learners in the university of enterprise is also manufacturing practitioners. Corporate university learners is relatively mature learners, have certain ability to learn, learning foundation. And they are both learner, innovators, and production of practitioners. Therefore, has a clear purpose of study, has strong autonomous learning willingness and motivation of independent learning. At the same time, the learning content to identify, select, evaluate ability is stronger. Learning ability also to have certain self perception and assessment.

Enterprise of the university of talent training and enterprise's production practice are merged [6]. Corporate university emphasizes the combination of workplace learning and action learning. Main characteristics can be summarized as: the production of practitioners with purpose of organizational knowledge innovation, knowledge learning, knowledge application and cultivation of talents in the process of production practice. The realization of the production, organic fusion was real.

(1) Learners, the teaching practitioners are production. Corporate university learners is the staff of the enterprise. The lecturer is enterprise senior managers, technical experts, business backbone enterprises, the general staff, etc. Instructors are mostly enterprise manufacturing practitioners.

(2) Learning process is the process of production practice. Corporate universities pay attention to the daily post production practice. Combined with specific tasks and specific research projects, specific decision-making management matters, purposeful, organized, systematic knowledge innovation, knowledge learning, knowledge application and talent training [7]. Teamwork is pay attention to in the process of production practice, production practice in the process of exchange and collaboration across different departments, professional is attention, and the production practice of mentoring type training be attention.

(3) Purpose of learning is to improve the production practice. Corporate university knowledge innovation, knowledge and talent training is the purpose of the study. Production practice is the inspection and evaluation of knowledge innovation, knowledge learning and application and the effective way of talent cultivation. To the quality and efficiency of the personnel training can be guaranteed. Therefore, traditional universities can learn enterprise university personnel training mode, to strengthen the close ties between university and with the enterprise in-depth cooperation [8]. Through concrete project of cultivating applied talents is to promote cooperation, at the same time, the direction and goal of talent training will be more clear. More targeted, more in line with market demand, the quality of personnel training efficiency will be improved.

\section{Corporate universities expand the higher education \\ learning form}

Corporate universities to serve the enterprise production practice and combining with production practices. Everybody is different positions of all employees in production practice. Comprehensive is all aspects of the production practice, or not with the production practice of departments, different jobs, different production process, etc. The whole is the whole process of the production practice.

(1) Corporate universities support of full-time study. Overall learning includes not only different career development stage, different positions and ranks of employees, and throughout every employee career development. Education training and the content of the study include: study pre-service training, job rotation training, professional certification training grade, professional ability training, formal recognition degree education, update knowledge skills training, career development stages education training, and the special study of unplanned.

(2) Corporate universities support comprehensive study. All aspects of the comprehensive study for production practice. Education training and the content of the study include: different professional posts and ranks of certification to learn. Proprietary knowledge, core knowledge learning. Such as enterprise culture and rules and regulations study, the enterprise's core business, management, product research and development, service innovation, best practices, knowledge learning. Total of knowledge, advanced experience, best practices, and other aspects of learning. In the enterprise value chain 
(3) Corporate universities to support the entire study. Corporate universities throughout the whole process of the production practice of learning. Education training and learning content includes: the whole process of enterprise strategic decision, the whole process of operation and management, the core business of the whole process involved in the ability of learning knowledge, Involved in enterprise overall development, the development of each department of the production practice and even the whole process of employee's individual career development, including learning requirements planning in all stages of development and the related content of learning [9].

Therefore, traditional university and other institutions of higher education and in-depth cooperation of the close ties between university and enterprise, it is helpful to university of traditional knowledge content of the update in time [10]. This kind of cooperation to strengthen the connection of theory and practice, to help the traditional form, method, mode of university innovation learning, so as to improve the teaching effect.

\section{E. Corporate universities expand the structure of higher education}

(1) Corporate universities expand the structure of higher education. Corporate universities expand the education of the higher education level type structure. Production practice requires a variety of level types of education. Corporate universities not only engaged in higher vocational education, adult education, continuing education, lifelong education, and engaged in education, education degree. Corporate university students changed the higher education structure [11]. Corporate university learners is given priority to with enterprise employees, age span is big, age structure diversification. So the nontraditional students growing proportion of higher education, students become more diversified. Corporate universities expand the capacity demand structure of higher education. Corporate universities expand the structure of supply and demand of higher education. Corporate universities can meet the learning needs of professional guidance, to provide practical industry authority certification training program, help to meet the different needs of learners, improve learners' employment competitive advantage [12]. So enterprise university or higher education will become the important supplement of competitors or collaborators, become the traditional higher education institutions, in order to make up for the inadequacy of traditional higher education, further meet the demand of diversification of higher education. Corporate universities expand the organizational structure and the knowledge structure of higher education. With corporate universities, combining the production practice of the organization structure and knowledge structure to follow production practice logic.

(2) corporate universities expand the function of higher education. Corporate universities to serve the parent enterprise as the basic function to a certain extent, expand the function of higher education. Corporate university of in service matrix enterprises at the same time, also in the whole social development of human capital and knowledge plays a more and more important role in the production of, constantly reveal its external social value, but also expand the function of higher education. The knowledge economy era, human capital elements become the core of the enterprise, corporate universities.

Through human capital development to serve the parent companies. Along with the development of knowledge economy, knowledge based enterprise production practice more and more become the important source of knowledge innovation, the enterprise has become an important subject of knowledge innovation, corporate universities are gradually developed into human society the knowledge of the important production department, become a key link in the process of knowledge circulation system.

(2) Corporate universities expand the function of higher education. Corporate universities to serve the parent enterprise as the basic function to a certain extent, expand the function of higher education. Corporate university of in service matrix enterprises at the same time, also in the whole social development of human capital and knowledge plays a more and more important role in the production of, constantly reveal its external social value, but also expand the function of higher education. The knowledge economy era, human capital elements become the core of the enterprise, corporate universities.

Through human capital development to serve the parent companies. Along with the development of knowledge economy, knowledge based enterprise production practice more and more become the important source of knowledge innovation, the enterprise has become an important subject of knowledge innovation, corporate universities are gradually developed into human society the knowledge of the important production department, become a key link in the process of knowledge circulation system.

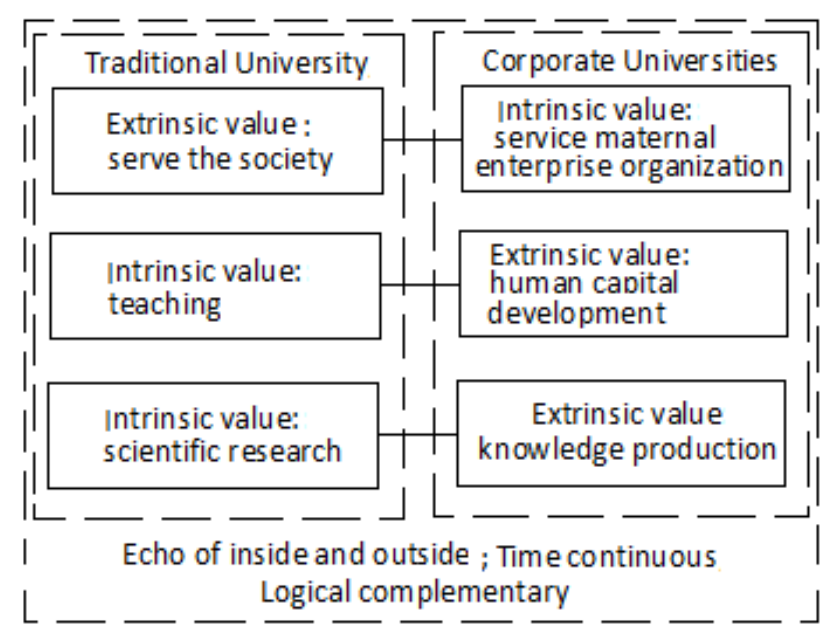

Figure 1. Function of corporate universities and the traditional university

Corporate universities and complementary to the traditional university function. Since corporate universities and the integration of production practice, it can fully reflect social reality in the field of production practice in a timely manner demand, therefore, traditional universities and corporate universities exist extensive cooperation space in terms of education, scientific research and serve the society [12]. 


\section{CORPORATE UNIVERSITIES PROMOTE THE INNOVATION OF HIGHER EDUCATION}

\section{A. Promote the efficiency of higher education}

Enterprise the purpose of the university knowledge production service knowledge is optimally achieve maximum efficiency. Corporate universities highly efficient embodied in various aspects, including the development of human capital, knowledge innovation efficiency, operation management efficiency is the key to realize knowledge efficiency. These three aspects is the traditional university and other institutions of higher education in the teaching, scientific research, management, and other aspects are worth learning and using for reference.

(1) The development of human capital. Elements of human capital is the core elements of an enterprise, the development of human capital directly influences the efficiency of enterprise development strategies, especially the relative lack of professional and technical personnel of the emerging industries. Corporate universities through specialization of knowledge production service can effectively shorten the industry experts, business backbone, corporate executives, the cultivation of the process.

(2) Knowledge innovation efficiency. The development of knowledge economy era, the enterprise is more and more dependent on knowledge innovation. Knowledge innovation is the core competence of university. Both the strategic decision making, development of the enterprise to change, and enterprise operation and management, the core business requires enterprise university knowledge innovation to provide strong support, and the efficiency of knowledge innovation is very important.

(3) The enterprise university operation management efficiency. Both the development of human capital and knowledge innovation efficiency, are relying on the enterprise university operation management. The core of operation management goal is to better service and achieve the development strategy of the enterprise. It is also a measure of enterprise operation management efficiency of the key university.

\section{B. Promote the diversification of education}

With the development of knowledge economy, on the basis of knowledge elements of social demand for higher education is becoming more and more diversified production practice. Social production practice promoted the ecological diversity of modern higher education. Rooted in the production practice of corporate universities to promote the diversification of higher education.

\section{Promoting the system innovation of higher education}

In order to adapt to the development of knowledge economy, promote the development of the knowledge innovation, knowledge, the modern higher education it is necessary to draw lessons from the enterprise of the university of related system, system, mechanism, so as to promote the higher education system, system, mechanism innovation, promote the development of knowledge productivity.

\section{CONCLUSIONS}

Social production practice plays an important role in the development of modern higher education. Social production practice promoted the ecological diversity of modern higher education, promoting the development of the knowledge system of modern higher education, promoting fundamental change of the modern higher education quality, content, form, scale, talent training .Corporate universities expanded the boundary of higher education, and corporate universities and the traditional functions of university are complementary. Corporate universities promote the development of higher education of informatization, intellectualization, internationalization and diversification. Corporate universities to promote the innovation of the higher education system and mechanism. In this paper, the boundary of the higher education development are analyzed by corporate universities, and innovation of higher education is to promote through corporate universities. Corporate universities promote the development of higher education towards diversification and informationization. Development of higher education innovation is inspired by the enterprise university, and it is of great significance for the innovation and development of higher education.

\section{REFERENCES}

[1] Song Xiling. Based on the perspective of adult education enterprise development research at the university of $[\mathrm{J}]$. Journal of hubei university adult education college, 2012, (10).

[2] Wu Feng. Based on the theory of enterprise model of human fields. Modern distance education research [J]. 2012, (3) : 75 - a - 79.

[3] Zhang Jing. Enterprise university research [M]. Beijing: economic science press, $2011(8): 27$.

[4] El-Tannir, A. The Corporate University Model for Continuous Learning[J]. Training and Development, Education Training,2002,44(2):76-81.

[5] Wu Feng. Enterprises to study research, based on the perspective of learning innovation [M]. Beijing: Beijing humanism publishing house. 2013.

[6] Anderson, L. Essential Part of Education Landscape: Corporate Universities - Virtual or Real - are Establishing Themselves Both in the US and in Europe[N]. Financial Times, 2002-03-25.

[7] Allen, Mark. Corporate Universities: Globalization and Greater Sophistication[J]. Journal of International Management Studies, 2010,5(10):48-53.

[8] Gao Qin and Long Yong, chang-lin ma, wen-liang guan. Mechanical and electrical integration of liquid system modeling and simulation technology $[\mathrm{M}]$. Beijing: electronic industry press. 2012.

[9] Allen, Mark. Corporate Universities. Globalization and Greater Sophistication[J]. Journal of International Management Studies, 2010, 5(1): 48-53.

[10] LuiAbel. Exploring the corporate university phenomenon: Development and implementation of a comprehensive survey [J].human resource development quarterly. 2012. 23 (1) :26-31.

[11] Xue Song li. Enterprises from four different point of view to study [J]. Engineering machinery today, 2009, (12) : 124-126.

[12] Wu Feng, the silver. And the trend of development of the enterprise to study research field. The higher engineering education research [J]. 2012, (4) : November 16. 